Case Report

\title{
GLOMUS TUMOR OF THE THUMB: CASE REPORT
}

\author{
T. A. Al-Sadek ${ }^{*}$, D. Niklev ${ }^{2}$, A. Al-Sadek ${ }^{3}$, L. Al-Sadek ${ }^{2}$ \\ ${ }^{1}$ Department of Orthopaedics and Traumatology, Belhoul European Hospital, Dubai, UAE \\ ${ }^{2}$ Faculty of Medicine, Trakia University, Stara Zagora, Bulgaria \\ ${ }^{3}$ Medical University, Sofia, Bulgaria
}

\begin{abstract}
We report on a case of glomus tumor in the right thumb. The tumor had a 2-year clinical history. The patient reported the development of a $3-5 \mathrm{~mm}$ tumor in the distal phalangeunder the nail of the right thumb. The patient also complained of severe and progressive pain. Tests using bidirectional Doppler and echo-color-Doppler revealed a presumptive diagnosis of arteriovenous malformation based on the turbulence of the flow and absence of stenosis. The tumor was removed by open surgery and sent for histopathological examination, which showed a diagnosis of glomangioma. The present report describes a rare disease causing extreme discomfort to the patient, which may be treated with surgical resection without sequelae.
\end{abstract}

Keywords: Glomus Tumor; Glomangioma; Thumb.

\section{INTRODUCTION}

The glomus tumor is a benign familial disorder. It originates from the glomus body, is often smaller than $3 \mathrm{~mm}$ and is formed by nerve, muscle and arterial components. This rare tumor accounts for less than $5 \%$ of the hand tumors and is more frequent in young women in their 20 to 40 years (1). It is often found in subungual regions, and its clinical presentation includes local hemorrhage. Its main characteristic is intense local pain. The diagnosis is made according to clinical symptoms, and only one third of the cases show radiological abnormalities, such as bone erosion (2-6), (25). The differential diagnosis should include other hand tumors, such as neurilemmoma, hemangioma, osteoma and schwannoma. Surgical removal results in cure and immediate pain relief.

\section{CASE REPORT}

A 48-year-old man presented with a tumor with a 4-month history, measuring about 3-5 $\mathrm{mm}$, extremely painful, located under the nail in the dorsal region of the right thumb. He denied any local trauma, exhaustive physical activity or any other probable cause of tumor formation. His pain worsened gradually, and he had an enlarged tumor mass and

\footnotetext{
*Correspondence to: Tabet Al-Sadek, M.D, Ph.D, Belhoul European Hospital, Dubai-UAE., Email: drthabet@abv.bg, Mobile: +971551503964
}

hyperesthesia in the first finger. He had been unsuccessfully treated with several non-steroid anti-inflammatory drugs and powerful analgesics.

Physical examination revealed an extremely painful tumor of about 3-5 $\mathrm{mm}$ in the dorsal aspect of the distal phalange in the right thumb. Pulses were normal, no abnormalities were found in the right upper extremity, and there were no thrills or murmurs in the arteries. The artery of the first finger was dilated and markedly pulsatile, which suggested an aneurism. Bidirectional Doppler scanning (Figure 1) of the radial artery of the thumb detected turbulent flow. Eco-color Doppler scanning revealed the presence of an arteriovenous malformation, a large number of collateral vessels and thrombophlebitis in the dorsal vein of the thumb. There is a hypersensitivity to hot and cold during the clinical examination of the thumb. Preoperative blood counts and clotting tests were normal.

\section{OPERATIVE TECHNIQUE AND RESULTS}

The patient underwent regional anesthesia of the right upper extremity using $1 \%$ lidocaine, with no vasoconstrictive agents. A skin incision was made, tissue layers were separated, and the vessels were carefully dissected. A large number of collateral veins 
were seen, and some had thrombosis $(7,24)$. The tumor was encapsulated, which was fully removed, and the pseudocapsule was preserved and sent to the laboratory for histopathology examination.
Immediately after operation ( 24 hours), pain disappeared. At follow-up, the patient was asymptomatic and had returned to work $(4,8)$.

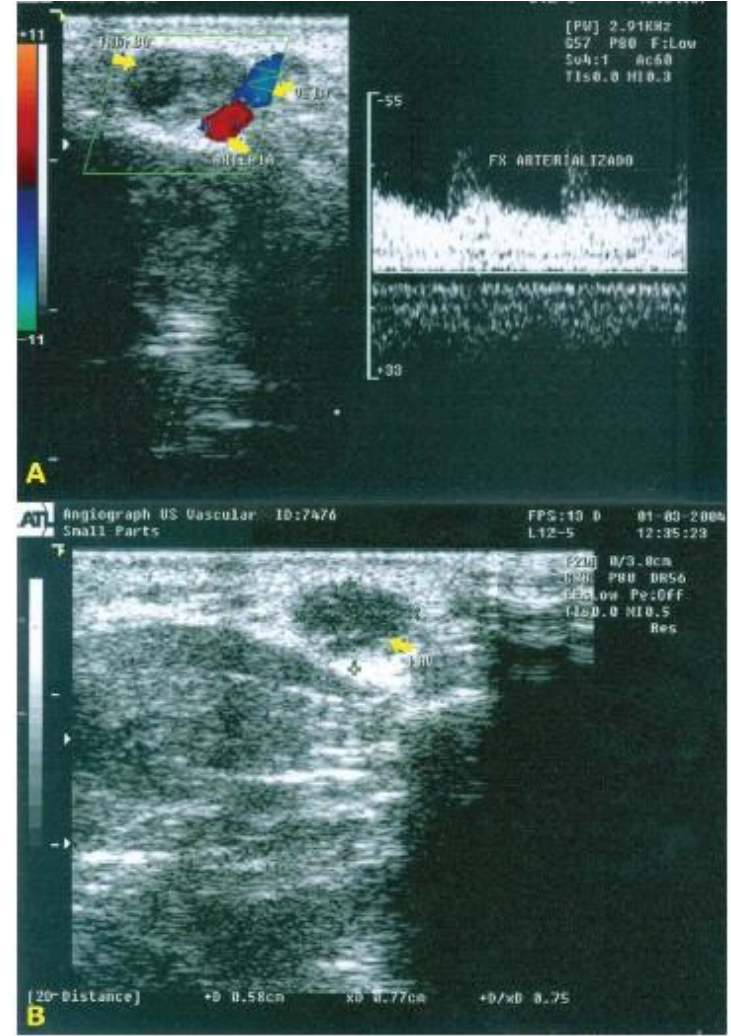

Figure 1. Imaging study. Echo Doppler

\section{HISTOPATHOLOGY}

Tumor made up of polygonal cells with small and regular nuclei, some in solid groups, but others in regularly organized cell threads. Few mitotic figures were found. Dilated and congested blood capillaries proliferated in the middle of the tumor cells, containing recent thrombi and covered by a single layer of endothelial cells (Figure 2).

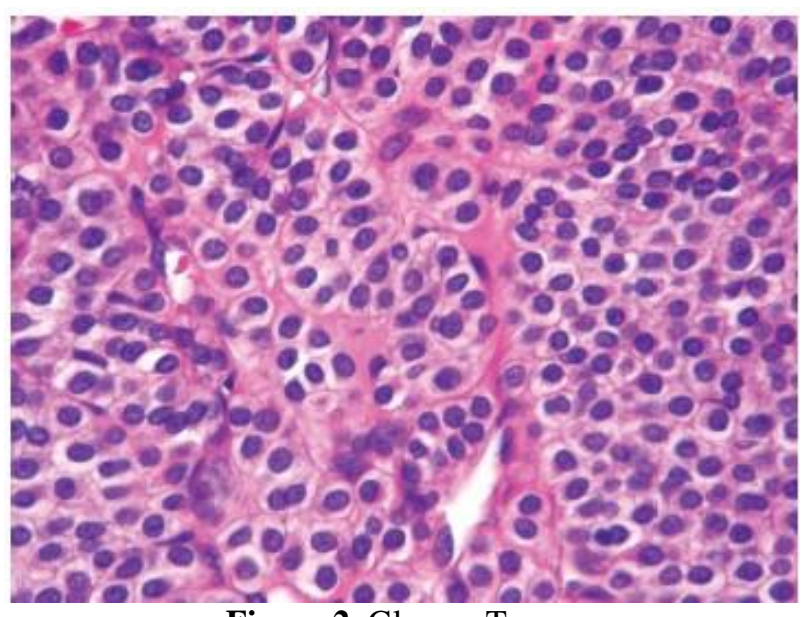

Figure 2. Glomus Tumor

\section{DISCUSSION}

A neuromyoarterial glomus and its tumor were first described by Masson (9) in 1924, and in 1972 Martorrel classified it as a glomangioma, or glomus tumor (23). It is formed by nervous fibers, muscle cells and vascular components and, for that reason; it was called glomangioma $(10,24)$.
It is a rare tumor and accounts for less than 2\% of all tumors that affect soft tissues. Its appearance and clinical history almost always involve some type of trauma. Pain is reported by all patients. In the beginning, pain is mild, but later becomes intense and unbearable. There is some regularity in time between pain episodes, but, as the disease progresses, pain 
frequency increases and the simple touch of clothing is often enough to trigger a crisis. Pain usually occurs at night, which makes it impossible for the patient to sleep. One of the hypotheses to explain pain intensity is based on tumor expansion, that is, as it is contained in a pseudocapsule, its growth is restricted, which leads to the necrosis of the central cells and their replacement by connective tissue. Another hypothesis to justify pain is tumor site, as it arises in the myoneural junction (11, $13,14)$.

The region most frequently affected by an extremity glomangioma is the dermis, the subcutaneous cell tissue, particularly in the nail bed, because there is little resistance to its development there, and not in small-caliber arteries, as Kamarashev et al (1) used to believe. These tumors may also be found in other sites, such as the stomach, knees, shoulder and mediastinum, as well as in the middle ear, where it may lead to serious balance disorders and hearing loss. They are benign tumors with a well defined oval shape, and they are never larger than $5 \mathrm{~mm}$, regardless of the region where they arise or its progression time $(15,16)$. When it is subungual and does not have space to grow, it loses its oval shape and may cause bone erosion, which may give the false impression of a malignant infiltrating tumor (15).

Imaging studies, such as arteriography and echo-color Doppler ultrasound, are useful to evaluate glomangiomas of the extremities, particularly to make the differential diagnosis with other tumors (15-18), but images are not conclusive.

Its diagnosis, in general, is made early on due to pain, but studies in the literature describe cases that had a history of 40 years. Some authors suggest that cell atypia is a result of the accumulation of heterochromatin associated with DNA inactivation. Moreover, the increased capillarity, the local architecture in the arrangement of tumor cells with uniform sizes and forms, and the uniformity of base cells suggest the diagnosis of glomus tumor. From the moment the diagnosis of a glomangioma is made, no other case of such tumor goes unnoticed by the examiner because of its particular characteristics.

Treatment is surgical using a conventional or laser technique, and the latter is applied in special to the cases of multiple glomangiomas. However, there may be tumor cell implantation the capsule ruptures, and a new tumor may be implanted, at a mean recurrence rate of $13.3 \%$
AL-SADEK T., et al.

(12). Tumor resection provides immediate symptom relief and complete pain resolution $(13,14,19,20)$. In this case, we chose an open surgery because total tumor removal was important to avoid the rupture of the capsule that contained it, the implantation of glomus cells and tumor recurrence (21), in agreement with treatment data in the literature (22).

\section{REFERENCES}

1. Kamarashev LE, French R, Dummer K. Symplastic glomus tumor - a rare but distinct begnin histological variant with analogy to other ancient begnin skin neoplasms. J CutanPathol, 36:1099-1102, 2009.

2. Ponnelle $T$, Gounny $P$, Boudghène $F$, et al. [Glomus tumor of the extremities]. $\mathrm{J}$ Mal Vasc, 24(5):7-364,1999.

3. Wong $\mathrm{CH}$, Chow L, Yen $\mathrm{CH}$, Ho PC, Yip $\mathrm{R}$, Hung LK. Uncommon hand tumours. Hand Surg, 6:67-80, 2001.

4. Pulitzer DR, Martin PC, Reed RJ. Epithelloid glomus tumor. Hum Pathol. 26:1022-7,1995.

5. Debol SM, Stanley MW, Mallery S, Sawinski E, Bardales RH. Glomus tumor of the stomach: cytologic diagnosis by endoscopic ultrasound-guided fineneedle aspiration. DiagnCytopathol. 28: 21$316,2003$.

6. Mentzel T, Hugel H, Kutzner H. CD34positive glomus tumor: clinicopathologic and immunohistochemical analysis of six cases with myxoid stromal changes. $J$ CutanPathol, 29: 5-421,2002.

7. Keefer CJ, Brantley B, DeLozier JB. Familial infiltrative glomangiomas: dignosis and treatment. J Craniofac Sur,7: 7-145, 1996.

8. Kim SW, Jung SN. Glomus tumour within digital nerve: A case report. $J$ PlastReconstrAesthetSurg,64:60-958,2011.

9. Masson P. Le glomus neuro-mioartérieldésrégionstactiles et séstumeurs. Lyon Chirurgical. 21:257,1924.

10.Bayley OT. The cutaneus glomus and its tumors-glomangiomas. Am J Pathol. 11:915, 1935.

11.Chong Y, Eom M, Min HJ, Kim S, Chung YK, Lee KG. Symplastic glomus tumor: a case report. Am J Dermatopathol. 31:71-3, 2009.

12.Fujioka $\mathrm{H}$, Kokubu $\mathrm{T}$, Akusue $\mathrm{T}$, et al. Treatment of subungual glomus tumor. Kobe J Med Sci, 55: E1-E4, 2009.

13. Monacelli G, Cascioli I, Mongardini M, Corelli S, Cigna E, Spagnoli AM. [Glomus tumor and neovascular syndrome of the 


\section{AL-SADEK T., et al.}

arm: a clinical case]. G Chir, 24:8-2350, 2003.

14.Kamano M, Kazuki K. Glomangioma arising from the superficial palmar arch in the hand: case report. ClinOrthopRelat Res, (419):4-162, 2004.

15.Tsuneyosshi M, Enjoji M. Glomus Tumor: a clinicopathologic and electron microscopic study. Cancer, 50: 7-1601, 1982.

16. De Candia A, Como G, Passon P, Pedace E, Bazzocchi M. Sonographic findings in glomus tynpanicum tumor. $J$ Clin Ultrasound, 30:236-40, 2002.

17. Vogl TJ, Juergens M, Balzer JO, et al. Glomus tumors of the skull base: combined use of MR angiography and spin-echo imaging. Radiology, 192:10-103, 1994.

18. Arnold SM, Strecker R, Scheffer K, et al. Dynamic contrast enhancement of paragangliomas of head and neck: evaluation with time-resolved 2D MR projection angiography. EurRadiol. 13:111608, 2003.

19. Sharma JK, Miller R. Treatment of multiple glomangioma with tuneable dye laser. $J$ Cutan Med Surg, 3: 8-167, 1999.
20.Chisci E, De Donato G, Setacci F, Perulli A, Galzerano G, Setacci C. A rare vascular tumour with distinctive clinical findings. $J$ CardiovascSurg, 49: 3-241,2008.

21.Dahlin LB, Besjakov J, Veress B. Scand A glomus tumour: classic signs without magnetic resonance imaging findings. $J$ PlastReconstrSurg Hand Surg,39:5123,2005.

22.Falleti J, Vita G, De Cecio R, et al. Symplatic glomus tumor: Report of a chalenging lesion with literature review. Pathol Res Pract,208:372-375,2012.

23.Fletcher CDM, Unni KK, Mertens F. WHO classification of tumors in: Pahology and Genetics of Tumors of Soft tissue and bone. Lyon: IARC Press; 2002.

24. Martorrel F. Angiologia EnfermidadesVasculares. Glomangiomas $e$ tumoresglomicos. Santiago de Chile: SalvatEditores S/A; pp. 470-477, 1972.

25.Robbins SL, Cotran RS, Kumar V. Patologiaestrutural e functional. Vasossanguíneos. Rio de Janeiro: Guanabara; pp. 3-522, 1986. 